\title{
З ДОСВІДУ РОБОТИ НАВЧАЛЬНО-ПРАКТИЧНИХ ЦЕНТРІВ УНІВЕРСИТЕТУ
}

\author{
М. М. Рожко, Г. М. Ерстенюк, В. В. Капечук, М. О. Іванців \\ ДВНЗ “Івано-Франківський національний медичний університет”
}

\section{FROM THE EXPERIENCE OF TRAINING AND PRACTICAL CENTER OF UNIVERSITY}

\author{
M. M. Rozhko, H. M. Erstenyuk, V. V. Kapechuk, M. O. Ivantsiv \\ SHEI "Ivano-Frankivsk National Medical University"
}

В ІФНМУ приділяється велика увага питанню практичної підготовки фахівців-медиків. В університеті створено навчально-практичні центри (НПЦ) “Медицина”, “Стоматологія”, “Фармація”, на базі яких студенти всіх факультетів та інтерни опановують практичні навички, готуються до державної атестації.

У всіх НПЦ розроблені та видані Алгоритми виконання практичних навичок українською, російською та англійською мовами, які під час практичних занять, а також самостійної позааудиторної роботи, допомагають студентам у набутті практичних вмінь та методик.

In IFNMU provide big attention for question practical training of medical professionals. In university created educational practice centers (EPC) "Medicine", "Dental", "Pharmacy" on which students of all faculties and interns have the opportunity to learn practical skills to prepare for state certification.

All EPC developed and published Algorithms of practical skills in Ukrainian, Russian and English languages, which during the workshops, as well as independent self-study work help students to acquire practical skills and methods.

Вступ. Основним завданням медичної освіти $\epsilon$ підготовка висококваліфікованого фахівця, що визначає місце фахівця в структурі системи охорони здоров'я і вимоги до його компетентності. Виходячи 3 цього, важливим завданням $\epsilon$ створення умов для розширення можливостей студентів-медиків в оволодінні практичними навичками та методиками.

В Івано-Франківському національному університеті (ІФНМУ) велика увага приділяється питанням практичної підготовки фахівців-медиків. Так, впродовж останніх трьох років проводиться активна робота 3 реалізації наказу МОЗ України № 782 від 11.11.2011 p. "Про впровадження Рішення наради ректорів вищих медичних (фармацевтичного) навчальних закладів IV рівня акредитації та закладів післядипломної освіти MO3 України "Підсумки проведення вступної кампанії до вищих навчальних закладів МОЗ України у 2011 році. Актуальні питання поліпшення якості та організації підготовки медичних та фармацевтичних спеціалістів", втілення Наскрізної програми підготовки студентів медичних факультетів вищих медичних навчальних закладів IV рівня акредитації та лікарівінтернів для оволодіння практичними навичками й методиками, необхідними для роботи на посадах лікарів за спеціальністю “Загальна практика - сімейна медицина”. Одним із важливих кроків було створення кафедри загальної практики (сімейної медицини), фізичної реабілітації та спортивної медицини для підготовки студентів медичного факультету, а також створення навчально-практичних центрів та забезпечення їх ефективної роботи.

Основна частина. В університеті впродовж 20112014 років створено навчально-практичні центри (НПЦ) "Медицина”, “Стоматологія”, “Фармація”, на базі яких студенти всіх факультетів та інтерни мають можливість опанувати практичні навички, підготуватись до державної атестації.

НПЦ “Медицина” функціонально об'єднує тренінгові кабінети кафедр внутрішньої медицини № 13 курсом клінічної імунології та алергології ім. акад. $€$. М. Нейка, внутрішньої медицини № 2, анестезіології та інтенсивної терапії (база ОКЛ), внутрішньої медицини № 3 та медсестринства (база ЦКМЛ), загальної практики (сімейної медицини), фізичної реабілітації та спортивної медицини (бази - Університетська клініка, гуртожиток № 4, амбулаторія с. Іваниківка), акушерства і гінекології ім. І. Д. Ланового (база ОПЦ), дитячої хірургії та пропедевтики педіатрії (база МДЛ). НПЦ “Медицина" має такі зали: “Догляд за 
хворими”, “Зондові маніпуляції”, “Зал ін'єкційної техніки”, “Функціональні методи дослідження. Невідкладна допомога”, зали для опрацювання практичних навичок з анестезіології та інтенсивної терапії, акушерства та гінекології, педіатрії.

НПЦ “Стоматологія” розміщений на базі стоматологічного факультету ІФНМУ і об'єднує десять фантомних та клінічних кімнат різного функціонального призначення, де студенти мають можливість засвоювати та опрацьовувати практичні навички 3 різних розділів профільних стоматологічних дисциплін.

У класі рентгенологічних методів обстеження змонтовано апарат для прицільної рентгенографії зубів і ортопантомограф. У фантомному класі хірургічної стоматології створено 10 робочих місць, кожне 3 яких обладнане стоматологічним фантомом 3 імітаторами верхньої та нижньої щелеп і штучними зубами. Ливарня входить до складу зуботехнічної лабораторії, де студенти навчаються технічного виконання етапів литва. Клінічна лабораторія дозволяє опанувати практичні навички виконання аналізів крові, пародонтологічних проб, визначення мікрострумів у порожнині рота, гістологічних та цитологічних досліджень. Клас профілактики та гігієни ротової порожнини обладнаний макетами щелеп, засобами гігієни ротової порожнини, де студенти мають змогу продемонструвати дітям заходи догляду за ротовою порожниною, виконати професійну гігієну порожнини рота. У класі дентальної імплантації створено 12 робочих місць. У фантомному класі кафедри ортопедичної стоматології студенти оволодівають практичними навичками технічного виконання лабораторних етапів виготовлення незнімних і знімних конструкцій зубних протезів. У класі складного (бюгельного) протезування студенти опрацьовують практичні навички з виконання етапів виготовлення сучасних кон- струкцій знімних бюгельних протезів. У кабінеті функціональної діагностики щелепно-лицевої ділянки встановлено електронейроміограф "Нейро-ЕМГмікро”, автоматизована система аналізу прикусу “Тscan III", апарат для визначення каріозних порожнин та твердих і м'яких під'ясенних зубних відкладень "Diagnodent" та аналізатор лазерної мікроциркуляції крові “Лакк-02".

НПЦ “Фармація” має у своєму складі 5 лабораторій, які дозволяють студентам опанувати практичні навички з дисциплін: фармацевтична ботаніка, фармакогнозія, ресурсознавство лікарських рослин; фармацевтична хімія, стандартизація лікарських засобів; аптечна технологія лікарських засобів, промислова технологія лікарських засобів, технологія косметичних лікарських засобів, біофармація, технологія лікарських засобів; неорганічна хімія, аналітична хімія, органічна хімія, фізколоїдна хімія, токсикологічна хімія; організація та економіка фармації, фармацевтичного та медичного товарознавства, менеджменту та маркетингу у фармації. У корпусі фармацевтичного факультету функціонує навчально-виробнича аптека.

В організації роботи НПЦ, крім матеріального оснащення, важливою є підготовка методичного забезпечення. У всіх НПЦ розроблені та затверджені Алгоритми виконання практичних навичок українською, російською та англійською мовами, які під час практичних занять, а також самостійно в позааудиторний час допомагають студентам набути практичних вмінь, оволодіти певними методиками.

Висновок. Створення НПЦ за спеціальностями та забезпечення їх Алгоритмами виконання практичних навиків та методик дає можливість студентам та інтернам повною мірою оволодівати знаннями та практичними навичками як під час навчальних занять, так і самостійної позааудиторної роботи.

Отримано 25.03.14 